\title{
Formulasi Cookies Kaya Serat Berbasis Tepung Terigu dan Tepung Ganyong (Canna edulis Kerr) dengan Penambahan Tepung Daun Kolesom (Talinum triangulare (Jacq.) Willd) Fiber-Rich Cookies Formulation Based on Wheat Flour and Canna Edible (Canna edulis Kerr) with the Addition of Kolesom Powder (Talinum triangulare (Jacq.) Willd)
}

\author{
Fajar Wibisono ${ }^{\mathrm{a}}$, Hermawan Seftiono ${ }^{\mathrm{a}^{*}}$ dan Moh. Taufik ${ }^{\mathrm{a}, \mathrm{b}}$ \\ a Program Studi Ilmu dan Teknologi Pangan, Fakultas Bioindustri, Universitas Trilogi \\ Jl. Duren Tiga Timur No.30, RT.5, Kalibata, Kec. Pancoran, Kota Jakarta Selatan, Daerah Khusus Ibukota Jakarta 12760 \\ ${ }^{b}$ Centre for Science and Technology, Universitas Islam Negeri Raden Mas Said Surakarta \\ Jl. Pandawa, Dusun IV, Pucangan, Kec. Kartasura, Kabupaten Sukoharjo, Jawa Tengah 57168
}

\section{Riwayat Naskah:}

Diterima 022021 Direvisi 042021 Disetujui 042021
ABSTRAK: Cookies umumnya dibuat dari tepung terigu yang merupakan bahan impor, sehingga ketergantungan terhadap bahan baku impor tersebut sangat besar. Substitusi tepung terigu dengan bahan lokal diperlukan untuk mengurangi ketergantungan bahan tersebut. Bahan lokal yang berpotensi digunakan adalah tepung umbi ganyong dan tepung daun kolesom. Penambahan tepung daun kolesom bertujuan untuk meningkatkan kandungan serat pada produk cookies dan juga sebagai pewarna alami. Tujuan penelitian ini adalah mengkarakterisasi sifat fisikokimia serta sensori cookies yang berbahan dasar tepung terigu dan tepung ganyong dengan penambahan tepung daun kolesom. Penelitian dilakukan dengan menggunakan dua faktor, yaitu persentase tepung umbi ganyong $(10 ; 20$ dan 30\%) dan tepung daun kolesom $(0 ; 2,5$ dan 5,0\%). Hasil penelitian ini diperoleh nilai rendemen dari tepung ganyong sebanyak 19,3\%, dan nilai rendemen dari tepung kolesom sebesar 8,55\%. Hasil uji hedonik terhadap aroma, warna, tekstur, rasa, dan aftertaste menunjukkan nilai yang bervariasi, yaitu tidak suka sampai sangat suka. Formula terpilih berdasarkan uji pembobotan adalah F3 yaitu cookies dengan subtitusi tepung ganyong 30\% dan penambahan tepung kolesom sebesar $5 \%$. Hasil analisis fisikokimia cookies ganyong F3 diperoleh kadar air sebesar 2,55\%, kadar abu 2,53\%, kadar protein 5,38\%, kadar lemak $29,8 \%$, kadar karbohidrat 58,69\% dan kadar serat pangan 15,60\% serta tingkat kekerasan 532,83 gf.

Kata kunci: cookies, sifat fisikokimia, sifat sensori, tepung ganyong, tepung kolesom

ABSTRACT: Cookies were generally made from wheat flour which is an imported ingredient, so the dependence on imported raw ingredient is very large. Substitution of wheat flour with local ingredients such as canna flour and kolesom leaf flour is needed to reduce dependence on these ingredients. The addition of kolesom leaf flour aims to increase the fiber content in cookies products and also as a natural dye. The purpose of this study was to characterize the physicochemical and sensory properties of cookies from wheat flour and canna flour with the addition of kolesom leaf flour. The research was carried out using two factors, namely the percentage of canna flour $(10,20$ and $30 \%)$ and kolesom leaf flour $(0,2.5$ and $5.0 \%)$. The results of this study obtained a yield value of canna flour as much as $19.3 \%$, and the yield value of kolesom powder was $8.55 \%$. The selected formulation in this study was F3 with 30\% canna flour substitution and 5\% kolesom powder. The physicochemical analysis of canna F3 cookies obtained moisture content of $2.55 \%$, ash content of $2.53 \%$, protein content of $5.38 \%$, fat content of $29.8 \%$, carbohydrate content of $58.69 \%$, dietary fiber content of $15.60 \%$ and hardness of $532.83 \mathrm{gf}$.

Keywords: cookies, physicochemical properties, sensory properties, canna flour, kolesom flour

\footnotetext{
Kontributor utama

Email : hermawan_seftiono@trilogi.ac.id
} 


\section{Pendahuluan}

Cookies termasuk salah satu makanan yang banyak digemari, baik anak-anak maupun dewasa (Affandi \& Ferdiansyah, 2017). Bahan baku utama dalam pembuatan cookies adalah tepung terigu yang diimpor dari negara lain, sehingga ketergantungan terhadap bahan baku tersebut besar. Data dari Kementerian Pertanian (2015) menunjukkan bahwa terjadi peningkatan rata-rata konsumsi per kapita tepung terigu sebesar 13,13\% dari tahun 2011 sampai 2015.

Saat ini telah banyak dikembangkan bahan lokal sebagai substitusi tepung terigu dalam pembuatan cookies. Menurut Budiarsih, Katri, \& Fauza (2010) perlu dicari bahan lokal yang digunakan untuk mengurangi penggunaan tepung terigu. Bahanbahan lokal yang telah dilakukan dalam mensubstitusi tepung terigu dengan bahan lokal adalah tepung tempe (Cipto, Efendi, \& Rossi, 2016; Seveline, Diana, \& Taufik, 2019; Taufik, Seveline, Susnita, \& Aida, 2019), sorgum (Rohajatien, 2010; Setiarto, Widhyastuti, \& Saskiawan, 2017; Mustika, Wahyuningsih, \& Paramita, 2019; Seveline, Divia, \& Taufik, 2021), tepung pisang (Silfia, 2012; Yasinta, Dwiloka, \& Nurwantoro, 2017; Anggraeni, 2019) dan sukun (Sukandar, Muawanah, \& Amelia, 2014; Sitohang, Lubis, \& Lubis, 2015; Novrini, 2020).

Alternatif bahan lain yang dapat digunakan adalah umbi-umbian lokal Indonesia. Menurut Rukmana (2000), Indonesia memiliki keragaman plasma nutfah yang sangat kaya, termasuk umbiumbian. Salah satu umbi-umbian yang berpotensi digunakan adalah ganyong (Canna edulis Kerr). Ganyong merupakan salah satu tanaman yang sudah familiar bagi penduduk Indonesia. Bagian tanaman ganyong yang umumnya digunakan adalah umbinya. Wiharto, Kurniawati, \& Karyantina (2016) menjelaskan pengolahan umbi ganyong umumnya dilakukan secara tradisional seperti digoreng, direbus dan dibakar. Lebih lanjut Rukmana (2000) menyatakan umbi ganyong juga bisa diolah menjadi beberapa produk seperti tepung ganyong, pati ganyong dan keripik ganyong.

Tepung ganyong dan pati ganyong dapat digunakan sebagai bahan alternatif untuk mereduksi penggunaan tepung terigu dalam produksi cookies. Beberapa penelitian menggunakan tepung umbi ganyong (Wiharto et al., 2016; Riskiani, Ishartani, \& Rachmawati, 2014) atau pati umbi ganyong (Harmayani, Murdiati, \& Griyaningsih, 2011; Istiqomah, Setyaningsih, \& Suryatna, 2019) untuk membuat cookies. Menurut Wiharto et al. (2016) dua kelebihan tepung ganyong dibandingkan tepung terigu yaitu kadar serat tinggi dan tidak mengandung gluten. Substitusi terigu dengan tepung ganyong akan memberikan nilai tambah pada cookies yang dihasilkan, yaitu kaya serat dan rendah gluten.

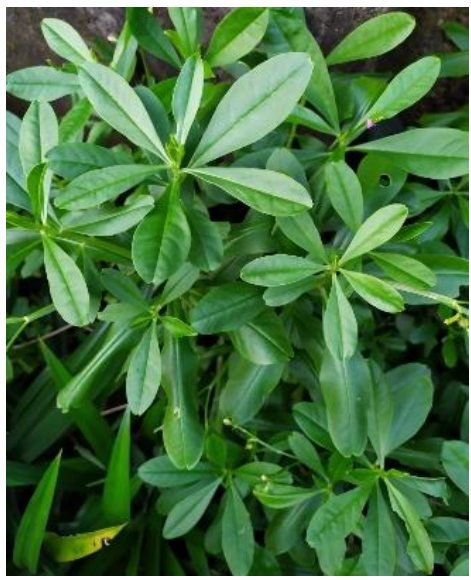

Gambar 1. Tanaman kolesom (Talinum triangulare (Jacq.) Willd)

Bahan lain yang terdapat di sekitar kita dan berpotensi digunakan sebagai bahan tambahan dalam produksi cookies untuk meningkatkan sifat fungsionalnya adalah daun kolesom (Talinum triangulare (Jacq.) Willd). Belum ada penelitian yang memanfaatkan daun kolesom dalam produksi cookies. Beberapa penelitian menggunakan daun kolesom untuk meningkatkan sifat fungsional dari produk yang mereka produksi, seperti dalam pembuatan crackers (Seftiono, Djiuardi, \& Chaesa, 2017; Seftiono, Djuardi, \& Pricila 2019) dan nori analog (Seftiono \& Puspitasari, 2019). Menurut Nugroho, Nuratmi, \& Winarno (2002) secara empiris daun kolesom dapat berfungsi sebagai obat diare, anti radang, afrodisiaka dan menambah vitalitas. Ekawati (2017) menambahkan dalam kolesom terkandung zat antioksidan, seperti asam fenolat dan antosianin.

Penelitian ini bertujuan untuk mengetahui pengaruh substitusi tepung umbi ganyong dan penambahan tepung daun kolesom terhadap sifat sensori (aroma, rasa, tekstur, warna dan aftertaste) dan sifat fisikokimia (kadar air, kadar abu, kadar protein, kadar lemak, kadar karbohidrat, kadar serat dan tekstur) dari cookies yang dihasilkan.

\section{Bahan dan Metode}

\subsection{Bahan}

Bahan-bahan yang digunakan untuk membuat cookies adalah tepung terigu protein tinggi (Cakra Kembar), umbi ganyong (Canna edulis Kerr) yang diperoleh dari salah satu toko online, daun kolesom Talinum triangulare (Jacq.) Willd) yang diperoleh dari perkebunan sendiri, margarin (Forvita), gula (GMP), garam, telur, dan baking powder (Kupukupu). 


\subsection{Alat}

Alat-alat yang digunakan pada penelitian ini adalah dehidrator (Excalibur, Amerika Serikat), penggiling tepung (Fomac, Indonesia), dan pengayak 80 mesh, mixer (Oxone, Indonesia), baskom, mangkuk, oven, loyang, cetakan kue, timbangan (Oxone, Indonesia), dan kuas.

\subsection{Metode}

\subsubsection{Pembuatan Tepung Ganyong}

Pembuatan tepung ganyong ini mengacu pada Slamet (2010) dengan modifikasi. Proses pembuatan tepung ganyong diawali dengan pengupasan dan pencucian umbi ganyong, dilanjutkan dengan pengirisan dengan ukuran \pm 2 $\mathrm{mm}$. Ganyong yang sudah diiris direndam dengan larutan $\mathrm{Na}$-bisulfit 2,5 g/L selama 20 menit, dilanjutkan dengan penirisan, pencucian, lalu pengeringan pada suhu $55-60{ }^{\circ} \mathrm{C}$ selama 8 jam, setelah dikeringkan, dilakukan penggilingan dengan penggiling tepung dan pengayakan 80 mesh.

\subsubsection{Pembuatan Tepung Daun Kolesom}

Pembuatan tepung daun kolesom ini mengacu pada Seftiono et al., (2019) dengan modifikasi. Proses pembuatan daun kolesom bubuk diawali dengan pencucian daun kolesom dan dikeringkan menggunakan dehidrator pada suhu $55-60{ }^{\circ} \mathrm{C}$ selama 21 jam, setelah kering dilakukan penggilingan dengan penggiling tepung dan pengayakan 80 mesh.

\subsubsection{Pembuatan Cookies}

Proses pembuatan cookies umbi ganyong ini mengacu pada Wiharto et al. (2016) dengan modifikasi. Proses produksi cookies diawali dengan mentega, garam dan gula halus dicampur dan diaduk, lalu kuning telur dicampurkan, selanjutnya tepung terigu, tepung ganyong, tepung daun kolesom, susu bubuk, garam dan baking powder dimasukkan dan diaduk sampai rata, lalu dicetak dan dipanggang dalam oven selama \pm 20 menit dengan suhu $140^{\circ} \mathrm{C}$ sampai matang.

Formula pada produksi cookies ini dapat dilihat pada Tabel 1. Cookies hasil produksi dianalisis sifat organoleptiknya yang meliputi aroma, warna, tekstur, rasa, dan aftertaste melalui uji hedonik sesuai SNI 01-2346-2006 Tata Cara Pengujian Organoleptik dan Sensori (BSN, 2006). Jumlah panelis yang digunakan adalah 30 panelis semi terlatih dan skala uji hedonik yang digunakan adalah 1 (sangat tidak suka)-5 (sangat suka). Cookies yang terpilih dari hasil uji hedonik dianalisis sifat fisikokimianya yaitu kadar air, kadar abu, protein, lemak, karbohidrat berdasarkan SNI 01-3775-2006 (BSN, 2006), serta kadar serat pangan total (AOAC, 1995) dan tekstur dianalisis dengan alat Texture Analyzer. Analisis proksimat dan kadar serat pangan dilakukan di PT. Saraswanti Indo Genetech (Bogor, Indonesia), sedangkan analisis tekstur dilakukan di Balai Besar Pasca Panen Bogor (Bogor, Indonesia).

Tabel 1

Formula Pembuatan Cookies

\begin{tabular}{lccccccc}
\hline \multirow{2}{*}{ Bahan } & \multicolumn{7}{c}{ Formula \% } \\
\cline { 2 - 8 } & K & F1 & F2 & F3 & F4 & F5 & F6 \\
\hline Tepung & & & & & & & \\
$\quad$ Tepung terigu & 100 & 90 & 80 & 70 & 90 & 80 & 70 \\
$\quad$ Tepung ganyong & 0 & 10 & 20 & 30 & 10 & 20 & 30 \\
Bahan lainnya* & & & & & & & \\
$\quad$ Tepung kolesom & 0 & 5 & 5 & 5 & 2.5 & 2.5 & 2.5 \\
Gula halus & 100 & 100 & 100 & 100 & 100 & 100 & 100 \\
Garam & 2,5 & 2,5 & 2,5 & 2,5 & 2,5 & 2,5 & 2,5 \\
Baking powder & 2,5 & 2,5 & 2,5 & 2,5 & 2,5 & 2,5 & 2,5 \\
Susu bubuk & 20 & 20 & 20 & 20 & 20 & 20 & 20 \\
Mentega & 150 & 150 & 150 & 150 & 150 & 150 & 150 \\
Telur & 50 & 50 & 50 & 50 & 50 & 50 & 50
\end{tabular}

Keterangan: *Persentase bahan lain dihitung berdasarkan total tepung

\subsubsection{Analisis Data}

Data diolah menggunakan SPSS dengan uji statistik one way ANOVA (Analysis of Varians) dengan derajat kepercayaan $95 \%$ dan dilanjutkan uji Tukey jika terdapat perbedaan nyata.

\section{Hasil dan Pembahasan}

\subsection{Tepung Ganyong dan Daun Kolesom}

Nilai rendemen dalam proses pembuatan tepung ganyong dan tepung daun kolesom dapat dilihat padat Tabel 2. Nilai rendemen yang diperoleh masih tergolong rendah. Hal ini kemungkinan karena kadar air bahan yang tinggi. Kadar air umbi ganyong hasil penelitian Utami dan Diyono (2011) pada beberapa varian ganyong berkisar 81,76-85,42\%. Semakin tinggi kadar air, maka nilai rendemen dalam proses pengeringan akan semakin rendah.

Tabel 2

Nilai Rendemen Pembuatan Tepung Ganyong dan Tepung Daun Kolesom

\begin{tabular}{lcc}
\hline Sampel & \multicolumn{2}{c}{ Rendemen (\%) } \\
\hline Tepung ganyong & 19,3 & $11,4^{*}$ \\
Tepung kolesom & 8,55 & $30^{* *}$ \\
\hline Keterangan: ${ }^{*}$ Richana \& Sunarti $(2004) ;{ }^{* *}$ Seftiono et al. (2019)
\end{tabular}


Nilai rendemen tepung ganyong yang diperoleh lebih tinggi dari Richana et al. (2004). Hal ini kemungkinan karena perbedaan waktu pengeringan yang digunakan dalam proses pembuatan tepung terigu ganyong. Richana et al. (2004) menggunakan suhu yang hampir sama, yaitu $50{ }^{\circ} \mathrm{C}$, tetapi dengan waktu lebih lama, yaitu 24 jam. Nilai rendamen tepung kolesom jauh lebih rendah dari yang diperoleh oleh Seftiono et al. (2019). Hal ini kemungkinan disebabkan oleh waktu pengeringan yang digunakan Seftiono et al. (2019) lebih singkat dibandingkan dengan penelitian ini, yaitu 17 jam.

\subsection{Cookies}

\subsubsection{Sifat Sensori}

\subsubsection{Aroma}

Hasil uji hedonik terhadap atribut aroma dapat dilihat pada Tabel 3. Hasil uji statistik, one wayAnova dan uji lanjut Tukey, menunjukkan aroma cookies kontrol berbeda nyata dengan cookies F1 hingga F6 ( $\mathrm{p}<0,05$ ). Perbedaan antara cookies kontrol dan cookies F1-F6 kemungkinan disebabkan oleh penambahan tepung daun kolesom yang mempengaruhi aroma pada cookies.

Tingkat kesukaan terhadap aroma dari cookies F1-F6 berkisar 2,93 (tidak suka-netral)-3,36 (netral-suka). Aroma cookies, selain kontrol, yang paling disukai adalah F2 dan F5. Hal ini menandakan substitusi tepung ganyong 20\% memberikan aroma yang disukai oleh panelis. Aroma cookies yang paling tidak disukai adalah F1. Hal ini kemungkinan karena persentase tepung kolesom yang ditambahkan paling tinggi, yaitu 5\%, dan juga tepung ganyong yang disubstitusi juga paling kecil, yaitu $10 \%$.

Tabel 3

Hasil Uji Hedonik dan Pembobotan

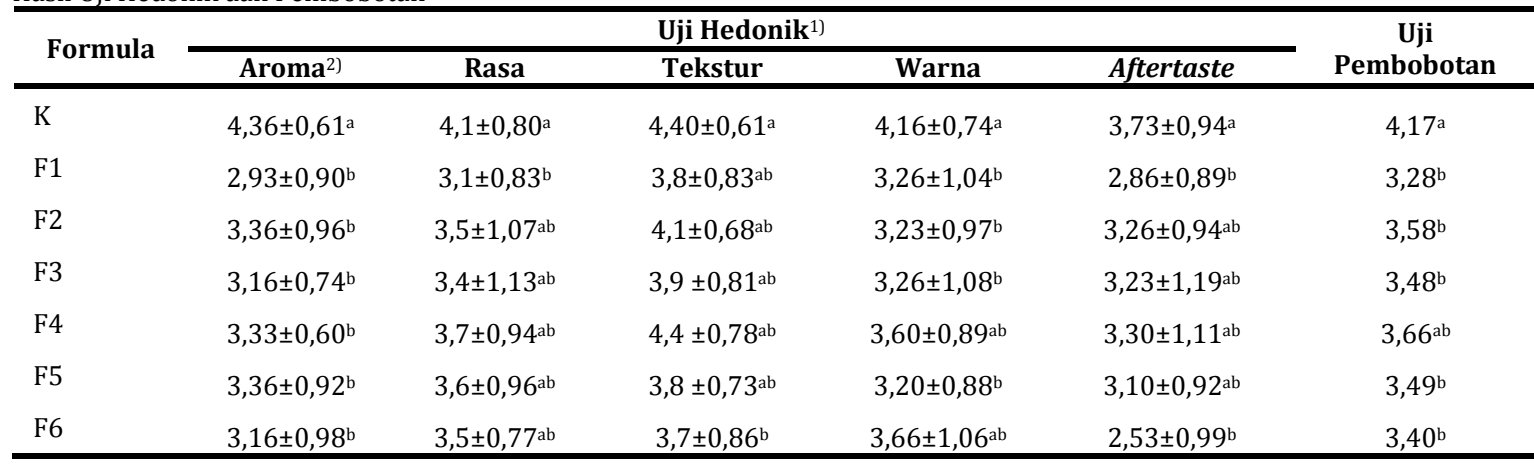

Keterangan: ${ }^{1)}$ Data di dalam tabel adalah rerata 3 ulangan \pm standar deviasi; ; ${ }^{2}$ Angka-angka pada kolom yang sama diikuti huruf superscript berbeda (a.b) menunjukkan berbeda nyata $(\mathrm{p}<0,05)$

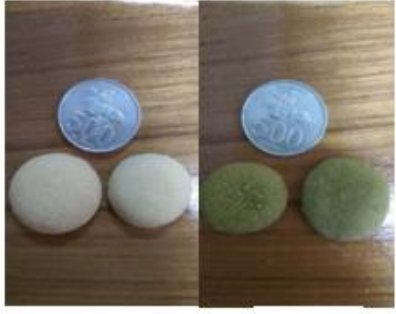

K

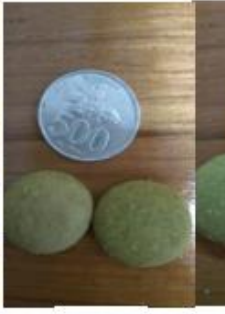

F2

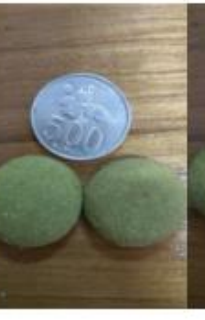

F3

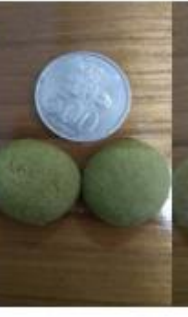

F4

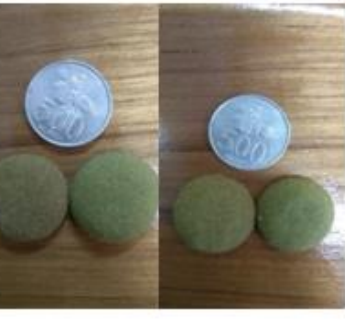

F5

F6

Gambar 2. Penampakan cookies ganyong

\subsubsection{Rasa}

Hasil uji hedonik pada atribut rasa dapat dilihat pada Tabel 3. Hasil uji statistik, one way-ANOVA dan uji lanjut Tukey, menunjukkan rasa pada kontrol berbeda nyata terhadap F1 tetapi tidak berbeda myata terhadap F2 hingga F6. Nilai atribut rasa cookies ganyong yang paling disukai, selain cookies kontrol, adalah $\mathrm{F} 4$ yang memiliki nilai ratarata 3,70 (netral-suka). F4 merupakan cookies dengan substitusi tepung ganyong dan penambahan tepung daun kolesom yang paling kecil. Panelis pada uji organoleptik ini kemungkinan lebih menyukai rasa cookies yang biasa mereka konsumsi, yaitu $100 \%$ terigu dan tidak ada penambahan tepung daun kolesom.

\subsubsection{Tekstur}

Hasil uji hedonik pada atribut tekstur dapat dilihat pada Tabel 3. Hasil uji statistik, one wayAnova dan uji lanjut Tukey, menunjukkan tekstur pada kontrol tidak berbeda nyata terhadap F1 hingga F5, tetapi berbeda nyata terhadap F6. Nilai 
tekstur cookies ganyong yang paling disukai adalah F4 dengan nilai 4,40 (suka-sangat suka). Hal ini kemungkinan disebabkan oleh persentase substitusi tepung ganyong dan penambahan tepung daun kolesom yang paling kecil dibandingkan formula cookies ganyong lain.

\subsubsection{Warna}

Hasil uji hedonik pada atribut warna dapat dilihat pada Tabel 3, sedangkan penampakan cookies dapat dilihat pada Gambar 2. Hasil uji statistik, yaitu one way-Anova dan uji lanjut Tukey, menunjukkan warna pada kontrol tidak berbeda nyata terhadap F1, F2, F3, dan F5, tetapi berbeda nyata terhadap F4 dan F6.

Hasil uji organoleptik menunjukkan warna cookies ganyong yang paling disukai adalah F6 dengan nilai 3,66 (netral-suka). Hal ini kemungkinan disebabkan oleh penambahan tepung daun kolesom yang paling kecil. Panelis kemungkinan lebih menyukai cookies yang sudah umum mereka kenal yang tanpa penambahan tepung kolesom.

\subsubsection{Aftertaste}

Hasil pengujian hedonik dapat dilihat pada Tabel 3. Hasil uji statistik, yaitu one way-Anova dan uji lanjut Tukey, menunjukkan aftertaste pada kontrol tidak berbeda nyata terhadap F2, F3, F5, dan F6, tetapi tidak berbeda nyata terhadap F1 dan F4. Nilai atribut aftertaste cookies ganyong yang paling disukai adalah F4 dengan nilai 3,30 (netral-suka). Hal ini kemungkinan karena penambahan tepung kolesom dan substitusi tepung ganyong yang paling kecil di antara semua formula cookies ganyong.

\subsubsection{Uji Pembobotan}

Nilai bobot dan hasil uji hedonik dengan uji pembobotan dapat dilihat pada Tabel 3 . Pertimbangan dalam pemilihan produk cookies terpilih pada penelitian ini ada dua faktor yaitu nilai uji Tukey terhadap hasil uji bobot dan persentase penggunaan tepung ganyong serta penambahan tepung dau kolesom.

Hasil uji Tukey, cookies F4 tidak berbeda nyata terhadap kontrol, sedangkan berdasarkan persentase substitusi tepung ganyong dan penambahan tepung daun kolesom, cookies F3 yang dipilih. Berdasarkan hasil uji organoleptik cookies F3 mempunyai nilai skor sensori atribut aroma, rasa, tekstur, warna dan aftertaste yang cukup baik, yaitu 3-4 (netral-suka). Produk yang akan dianalisis sifat fisikokimianya adalah cookies F3. Hal ini disebabkan dari nilai uji Tukey F3 tidak berbeda nyata terhadap F4 serta persentase penggunaan tepung ganyong dan tepung kolesom yang terbesar dibandingkan formula lainnya.

Tabel 4

Hasil Analisis Sifat Fisikokimia Cookies

\begin{tabular}{|c|c|c|c|}
\hline \multirow{2}{*}{ Pengujian } & \multicolumn{2}{|c|}{ Sampel $^{1)}$} & \multirow{2}{*}{ SNI 2973:2011 } \\
\hline & Kontrol & F3 & \\
\hline Kadar air (\%) & $2,53 \pm 0,02$ & $2,55 \pm 0,04$ & Maks 5 \\
\hline Kadar abu (\%) & $2,14 \pm 0,00$ & $2,53 \pm 0,00$ & Maks 1,6 \\
\hline Kadar protein (\%) & $5,44 \pm 0,00$ & $5,38 \pm 0,00$ & Min 5 \\
\hline Kadar lemak (\%) & $31,16 \pm 0,00$ & $29,8 \pm 0,00$ & Maks 10 \\
\hline Karbohidrat (\%) & $60,59 \pm 0,00$ & $58,69 \pm 0,00$ & Min 70 \\
\hline Tekstur (gf) & 334,67 & 532,83 & - \\
\hline Kadar serat pangan (\%) & $12,78 \pm 0,00$ & $15,60 \pm 0,00$ & - \\
\hline
\end{tabular}

Keterangan: ${ }^{1)}$ Data di dalam tabel adalah rerata 3 ulangan \pm standar deviasi

\subsubsection{Sifat Fisikokimia}

\subsubsection{Kadar air}

Kadar air merupakan salah satu faktor penting yang menentukan tekstur dan umur simpan produk cookies. Hasil analisis kadar air produk cookies ganyong dan kontrol dapat dilihat pada Tabel 4 .

Berdasarkan hasil pada Tabel 4, kadar air pada F3 $(2,55 \%)$ sedikit lebih besar dari kontrol (2,53\%). Hal ini kemungkinan karena kadar air tepung ganyong lebih tinggi dari tepung terigu. Data dari Direktorat
Gizi Depkes RI (2005), kadar air pada tepung ganyong sebesar 14,0\% lebih besar jika dibandingkan dengan tepung terigu yang memiliki kadar air 12,0\%. Kadar air cookies ganyong pada penelitian ini lebih kecil dari cookies hasil penelitian Wiharto et al. (2016), yaitu 3,4439- 3,6953\%. Hal ini kemungkinan karena perbedaan besarnya substitusi tepung ganyong yang berkisar antara 25-75\%. Kadar air cookies ganyong telah memenuhi syarat SNI 2973:2011 Biskuit dengan kadar air maksimal sebesar 5\% (BSN, 2011). 
Citation: Wibisono, F., Seftiono, H., \& Taufik, M. (2021) Formulasi cookies kaya serat berbasis tepung terigu dan tepung ganyong (Canna edulis Kerr) dengan penambahan tepung daun kolesom (Talinum triangulare (Jacq.) Willd). Warta IHP, 38(1), 1-8

Halaman | 6

\subsubsection{Kadar $a b u$}

Hasil analisis kadar abu produk cookies ganyong dan kontrol dapat dilihat pada Tabel 4. Berdasarkan hasil pada Tabel 4, F3 $(2,53)$ memiliki kadar abu yang lebih besar dibandingkan dengan kontrol $(2,14 \%)$. Kandungan kadar abu yang terkandung pada tepung ganyong lebih tinggi dibandingkan dengan tepung terigu. Menurut penelitian Budiarsih et al. (2010), kadar abu pada tepung ganyong sebesar 4,245\%, sedangkan menurut penelitian Hartanto (2012) kadar abu pada tepung terigu sebesar 0,60\%. Berdasarkan dari data dan hasil tersebut, dapat disimpulkan bahwa adanya penambahan tepung ganyong pada produk cookies akan mempengaruhi kadar abu yang terkandung di dalamnya. Hasil kadar abu produk cookies ganyong tidak memenuhi syarat SNI 2973:2011 Biskuit dengan kadar abu maksimal 1,6\% (BSN, 2011).

\subsubsection{Kadar protein}

Hasil analisis kadar protein produk cookies ganyong dan kontrol dapat dilihat pada Tabel 4 . Berdasarkan hasil dari tersebut, kadar protein F3 $(5,38 \%)$ hampir sama dibandingkan dengan kontrol $(5,44 \%)$. Hasil kadar protein tersebut dipengaruhi oleh penambahan tepung ganyong. Tepung ganyong sendiri tidak memiliki kandungan gluten di dalamnya. Menurut Budiarsih et al. (2010), semakin tinggi kandungan glutennya, maka semakin tinggi pula kandungan protein yang terdapat di dalam produk pangan tersebut.

Kadar protein pada kontrol dan F3 sudah sesuai dengan SNI yang telah ditetapkan oleh Badan Standardisasi Nasional (BSN). Sesuai dengan SNI 2973:2011 yang telah menetapkan batas minimal kandungan kadar protein pada cookies yaitu dengan batas minimal 5\% (BSN, 2011).

\subsubsection{Kadar lemak}

Kadar lemak cookies ganyong dan kontrol dapat dilihat pada Tabel 4. Berdasarkan hasil dari Tabel 4, F3 (31,16\%) memiliki kandungan lemak yang lebih sedikit dibandingkan dengan kontrol (29,8\%). Kandungan tepung ganyong memiliki lemak yang jauh lebih sedikit dibandingkan dengan tepung terigu, yaitu hanya sebesar 0,1g/100 g sedangkan tepung terigu memiliki kandungan lemak sebesar 1,30g/100g tepung terigu (Direktorat Gizi Depkes RI, 2005). Kandungan lemak pada tepung sangatlah berpengaruh terhadap produk cookies, semakin tinggi kandungan lemak pada tepung tersebut, semakin tinggi pula kandungan lemak pada produk cookies. Hasil uji kadar lemak produk cookies ganyong tidak memenuhi syarat SNI-01-2973-2011
Biskuit dengan kadar lemak maksimal 10\% (BSN, 2011).

\subsubsection{Kadar Karbohidrat (by difference)}

Hasil pengujian kadar karbohidrat dapat dilihat pada Tabel 4. Berdasarkan hasil dari tersebut, kandungan karbohidrat pada kontrol $(60,59 \%)$ lebih besar dibandingkan dengan F3 (58,69\%). Kadar karbohidrat yang dihitung secara by difference dipengaruhi oleh komponen nutrisi lain. Menurut Riskiani et al. (2014) semakin rendah komponen nutrisi yang lainnya (air, abu, lemak, dan protein), maka akan semakin tinggi nilai kadar karbohidrat suatu produk. Kadar karbohidrat yang terkandung dalam bahan baku juga berpengaruh. Menurut Anggraeni (2019), kadar karbohidrat cookies dipengaruhi oleh bahan baku yang digunakan. Hasil uji kadar karbohidrat produk cookies ganyong tidak memenuhi syarat SNI-01-2973-2011 dengan kadar karbohidrat minimal $70 \%$.

\subsubsection{Tekstur}

Nilai tingkat kekerasan cookies kontrol dan F3 dapat dilihat pada Tabel 4. Sampel F3 (532,83 gf) memiliki tingkat kekerasan yang lebih besar dibandingkan dengan kontrol (334,67 gf). Menurut Guo, Jackson, Graybosch, \& Parkhurst (2003) kekerasan dipengaruhi oleh kadar amilosa pada suatu produk. Menurut Purwaningsih et al. (2013) kadar amilosa pada pati ganyong sebesar 32,8$35,34 \%$, sedangkan menurut Pradipta dan Putri (2015), tepung terigu mengandung amilosa sebanyak 28\%. Riskiani et al. (2014) menambahkan bahwa kandungan amilosa yang tinggi pada tepung akan menghasilkan produk pangan yang kaku, sulit mengembang dan bertekstur keras.

\subsubsection{Serat}

Hasil penelitian kadar serat pangan cookies ganyong dapat dilihat pada Tabel 4. F3 dengan subtitusi tepung ganyong 30\% dan tepung daun kolesom sebanyak 5\% memiliki kandungan kadar serat pangan $(15,60 \%)$ yang lebih tinggi dibandingkan dengan cookies kontrol $(12,78 \%)$. Hal ini kemungkinan karena penambahan tepung ganyong dan tepung daun kolesom dapat meningkatkan kandungan serat pada cookies ganyong ini. Hasil penelitian Riskiani et al. (2014) menunjukkan umbi ganyong memiliki kandungan serat alami cukup tinggi yaitu sebesar 2.20\%, dibandingkan dengan kadar serat pada tepung terigu sebesar $2,00 \%$. 


\section{Kesimpulan}

Nilai rendemen tepung ganyong dan tepung kolesom adalah $19,3 \%$ dan $8,55 \%$. Produk cookies ganyong yang ditambah tepung kolesom memiliki warna, aroma, rasa, dan tekstur yang tergolong dapat diterima oleh panelis. Berdasarkan pertimbangan persentase substitusi tepung ganyong dan penambahan tepung daun kolesom yang besar, serta hasil uji organoleptik yang cukup baik, maka formula yang dipilih adalah F3, yaitu dengan formula tepung terigu $70 \%$ dan tepung ganyong $30 \%$ dan penambahan tepung kolesom 5\%. Cookies ganyong F3 memiliki kadar air, abu, protein, lemak, dan karbohidrat berturut-turut sebesar 2,55; 2,53; 5,38; 29,8; dan 58,69\%. Cookies tersebut juga mempunyai nilai tingkat kekerasan 532,83 gf, dan kadar serat pangan sebesar 15,60\%. Cookies dengan penambahan serbuk kolesom ini berpotensi menjadi cookies fungsional.

\section{Ucapan Terima Kasih}

Ucapan terima kasih disampaikan kepada PT. Saraswanti Indo Genetech dan Balai Besar Pasca Panen Bogor yang telah membantu dalam analisis melalui jasa analisis yang ditawarkan. Ucapan terima kasih juga disampaikan kepada Evan Prasetya selaku asisten laboratorium Program Studi Ilmu dan Teknologi Pangan, Universitas Trilogi yang telah membantu dalam pelaksanaan penelitian.

\section{Daftar Pustaka}

[AOAC] Association of Official Analytical Chemistry. (1995). Official Methods of Analysis. Washington DC: AOAC Inc.

[BSN] Badan Standardisasi Nasional. (2006). SNI 012346-2006 Tata Cara Pengujian Organoleptik dan Sensori. Jakarta: Badan Standardisasi Nasional.

[BSN] Badan Standardisasi Nasional. (2006). SNI 013775-2006 Kornet Daging Sapi. Jakarta: Badan Standardisasi Nasional.

[BSN] Badan Standardisasi Nasional. (2011). SNI 2973:2011 Biskuit. Jakarta: Badan Standardisasi Nasional.

Anggraeni, R. (2019). Karakterisasi sifat kimia dan organoleptik cookies substitusi tepung pisang nangka mentah (Musa sp. L). Agrikan: Jurnal Agribisnis Perikanan, 12(2), 248-257.

Affandi, A. R., \& Ferdiansyah, M. K. (2017). Karakterisasi sifat fisiko-kimia dan organoleptik produk cookies tersubstitusi tepung suweg (Amorphophallus campanulatus BI). Jurnal Pangan dan Gizi, 7(1), 9-16.

Budiarsih, D. R., Katri, R. B., \& Fauza, G. (2010). Kajian penggunaan tepung ganyong (Canna edulis Kerr) sebagai subtitusi tepung terigu pada pembuatan mie kering. Jurnal Teknologi Hasil Pertanian, 3(2), 87-94.

Cipto, D., Efendi, R., \& Rossi, E. (2016). Pemanfaatan tepung tempe dengan penambahan bubuk kayu manis dalam pembuatan kukis dari sukun. JOM Faperta, 3(2), 1-12.

Direktorat Gizi Depkes RI. (2005). Daftar Komposisi Zat Gizi Pangan Indonesia. Jakarta: Departemen Kesehatan RI.

Ekawati, R. (2017). Pertumbuhan dan produksi pucuk kolesom pada intensitas cahaya rendah. Kultivasi, 16(3). 412-417.

Guo, G., Jackson, D. S., Graybosch, R. A., \& Parkhurst, A. M. (2003). Asian salted noodle quality: Impact of amylose content adjustments using waxy wheat flour. Cereal Chemistry, 80(4), 437445.

Harmayani, E., Murdiati, A., \& Griyanigsih. (2012). Karakterisasi pati ganyong (Canna edulis) dan pemanfaatannya sebagai bahan pembuatan cookies dan cendol. Agritech, 31(4), 297-304.

Hartanto, E. S. (2012). Kajian penerapan SNI produk tepung terigu sebagai bahan makanan. Jurnal Standardisasi, 14(2), 164-172.

Istiqomah, A. N., Setyaningsih, D. N., \& Suryatna, S. (2019). Eksperimen pembuatan egg drop cookies berbahan dasar tepung pati umbi ganyong (Canna edulis Ker). Teknobuga, 7(1), 1-8.

Kementerian Pertanian. (2015). Statistik konsumsi pangan tahun 2015. Jakarta: Pusat Data dan Sistem Informasi Pertanian Kementerian Pertanian

Mustika, A., Wahyunigsih, \& Paramita, O. (2019). Pengaruh teknik perendaman pada pembuatan tepung sorgum merah (Bicolor L) ditinjau dari kualitas butter cookies. Teknobuga, 7(1), 22-30.

Novrini, S. (2020). Pengaruh persentase tepung sukun dalam campuran tepung dan gula terhadap mutu cookies sukun. AGRILAND Jurnal Ilmu Pertanian, 8(1), 61-65.

Nugroho, Y. A., Nuratmi, B., \& Winarno, M. W. (2007). Kolesom (Talinum triangulare Willd.) tumbuhan berkhasiat afrodisiaka yang aman. Puslitbang Biomedis Dan Farmasi Badan Litbangkes, 35(3), 108-114.

Pradipta, I. B. Y. V., \& Putri, W. D. R. (2014). Pengaruh proporsi tepung terigu dan tepung kacang hijau serta subtitusi dengan tepung bekatul dalam biskuit. Jurnal Pangan dan Agroindustri, 3(3) : 793-802.

Purwaningsih, H., Irawati, R., \& Riefna. (2013). Karakteristik Fisiko Kimia Tepung Ganyong sebagai Pangan Alternatif Pengganti Beras. Yogyakarta: Balai Pengkajian Teknologi Pertanian (BPTP). 
Richana, N., \& Sunarti, T. C. (2004). Karakterisasi sifat fisiko kimia tepung umbi dan tepung pati dari umbi ganyong, suweg, ubi kelapa dan gembili. J.Pascapanen, 1(1), 29-37.

Riskiani, D., Ishartani, D., \& Rachmawati, D. (2014). Pemanfaatan tepung umbi ganyong (Canna edulis Ker.) sebagai pengganti tepung terigu dalam pembuatan biskuit tinggi energi protein dengan penambahan tepung kacang merah (Phaseolus vulgaris L). Jurnal Teknosains Pangan, 3(1), 1-10.

Rohajatien, U. (2010). Studi tentang pemrosesan tepung sorgum terfosforilasi dan aplikasinya pada berbagai adonan pastri. Teknologi Dan Kejuruan, 33(1), 93-106.

Rukmana, R. (2000). Ganyong Budidaya dan Pascapanen. Yogyakarta: Kanisius

Seftiono, H., Djiuardi, E., \& Chaesa, D. (2017, October 10-11). Analisis mutu sensoris, sifat fisik, dan mikrobiologi cracker yang difortifikasi tepung tempe dan tepung kolesom. Seminar Nasional PATPI 2017. Bandar Lampung

Seftiono, H., \& Puspitasari, D. (2019). Analisis organoleptik dan kadar serat nori analog daun kolesom (Talinum triangulare (Jacq.) Willd). Jurnal Bioindustri, 2(1), 59-66.

Seftiono, H., Djiuardi, E., \& Pricila, S. (2019). Analisis Proksimat dan Total Serat Pangan pada Crackers Fortifikasi Tepung Tempe dan Koleseom (Talinum Tiangulare). AgriTECH, 39(2), 160-168.

Setiarto, R. H. B., Widhyastuti, D., \& Saskiawan, I. (2017). Karakteristik amilografi tepung sorgum fermentasi dan aplikasinya pada produk cake dan cookies. Jurnal Dinamika Penelitian Industri, 28(1), 10-19.

Seveline, S., Diana, N., \& Taufik, M. (2019). Formulasi cookies dengan fortifikasi tepung tempe dengan penambahan rosela (Hibiscus sabdariffa L.). Jurnal Bioindustri, 1(2), 245-260.

Seveline, S., Divia, I. P., \& Taufik, M. (2021). Pengaruh substitusi tepung sorgum fermentasi terhadap karakteristik fisik, kimia dan organoleptik kukis. Agrointek, 15(1), 115-125.
Silfia, S. (2012). Pengaruh substitusi tepung pisang terhadap mutu kue kering. Jurnal Litbang Industri, 2(1), 43-49.

Simanungkalit, L. P., Subekti, S., \& Nurani, A. S. (2018). Uji penerimaan produk cookies berbahan dasar tepung ketan hitam. Media Pendidikan, Gizi, dan Kuliner, 7(2), 31-43.

Sitohang, K. A. K., Lubis, Z., \& Lubis, L. M. (2015). Pengaruh perbandingan jumlah tepung terigu dan tepung sukun dengan jenis penstabil terhadap mutu cookies sukun, J.Rekayasa Pangan dan Pert. 3(3): 308-315.

Slamet, A. (2012). Pengaruh perlakuan pendahuluan pada pembuatan tepung ganyong (Canna edulis) terhadap sifat fisik dan amilografi tepung yang dihasilkan. Agrointek, 4(2), 100103.

Sukandar, D., Muawanah, A., Amelia, E. R., \& Basalamah, W. (2014). karakteristik cookies berbahan dasar tepung sukun (Artocarpus communis) bagi anak penderita autis. Jurnal Kimia Valensi, 4(1), 13-20.

Taufik, M., Seveline, Susnita, S., Aida, D. Q. (2019). Formulasi cookies berbahan tepung terigu dan tepung tempe dengan penambahan tepung pegagan. Jurnal Agroindustri Halal, 5(1), 9-16.

Utami, N. W., \& Diyono, D. (2016). Respon pertumbuhan dan produksi 4 varian ganyong (Canna edulis) terhadap intensitas naungan dan umur panen yang berbeda. Jurnal Teknologi Lingkungan, 12(3), 333-343.

Wiharto, I., Kurniawati, L., \& Karyantina, M. (2008). Karakteristik cookies dengan substitusi tepung ganyong (Canna edulis Ker) dengan berbagai perlakuan pendahuluan. Jurnal Teknologi Dan Industri Pangan, 1(1), 1-8.

Yasinta, U., Dwiloka, B., \& Nurwantoro. (2017). Pengaruh subtitusi tepung terigu dengan tepung pisang terhadap sifat fisikokimia dan organoleptik cookies. Jurnal Aplikasi Teknologi Pangan, 6(3), 119-123. 